International Journal of Engineering \& Technology, $7(3.30)(2018) 198-201$
International Journal of Engineering \& Technology
SPC
Website www.sciencepubco.com/index.php/IJET
Research paper

\title{
Quantum Learning of Eel Dr. C: Maximizing Students' Civics Education Achievement
}

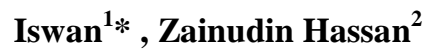 \\ ${ }^{I}$ Faculty of Education, Muhammadiyah University of Jakarta \\ ${ }^{2}$ Faculty of Education, Universiti Teknologi Malaysia \\ *Corresponding author E-mail: iswanfipumj@gmail.com
}

\begin{abstract}
The aims of this research are: (1) to investigate the effectiveness of Quantum Learning of EEL Dr. C in maximizing students' civics education achievement, (2) to find out to what extent Quantum Learning of EEL Dr. C influences students' civics education achievement This is a quantitative research study which applied quasi-experimental research design. A total number of 60 students of State Primary School 1 Cirendeu, Ciputat, South Tangerang, Indonesia participated in this study.These subjects were directly assigned into experimental and control classes. A set of multiple choice pre- and post-test was used to collect the data after being validated. The independent $\mathrm{t}$-test was used in analyzing the data. The findings of the research revealed that there is a significant difference of mean scores of students' civics education achievement in which those in experimental group reached higher mean score than those in the control group. Thus, the conclusion of this study responsed to the aims of the research as follows: (1) Quantum Learning Cycles of EEL Dr. C is effective in maximizing students' achievement; (2)
\end{abstract}

Keywords: Civics education, Quantum learning model, Quantum learning of EEL Dr. C.

\section{Introduction}

Education is an important factor inside human existence. It is accordingly the foundation upon which students can reach academic achievement. It is not just about teaching the students to be good. It is teaching them to be their best. It can be said that the main aim of learning achievement is to provide individuals self-actualization as a whole. In the context of education in Indonesia, the aim of national education in general is to prepare future generations to become citizens who have good characters and nationalism. Thus, Civic education is taught starting from primary until higher education. As it is stated in National Education Law No. 20/2003, article 37, paragraph 1 that "the curriculum of primary and secondary education must contain:"... b. Civic Education...". Civic education is important to be introduced to early students (Primary level students) in order to give those young learners strong foundation before they reach their higher levels of learning. This education should be taught in such a way so that the students will enjoy the lesson without reducing moral values delivered in this subject.

Learning process should be fun for children. The presence of high learning interest will make students easy to accept and to process the subjects presented [1]. Realizing that learning is an active process, Quantum Learning as an educational model tries to provide complex educational theories through immediate, effective and consistent implementation in class [2]. It requires not only the process of brain's understanding but also the information coming from the outer world to be practiced according to certain rules. Quantum learning is about bringing joy to teaching and learning with ever-increasing 'Aha' moments of discovery (https:www.scribd.com).

\section{Literature Review}

\subsection{Quantum Learning Model}

Bobbi Deporter, the President of the Quantum Learning Network (QLN), stated that Quantum Learning is a system that artfully orchestrates learning and increases teacher effectiveness while facilitating student mastery of rigorous academic content. The Quantum Learning System focuses on what teachers and students do to teach and learn effectively [3]. Quantum Learning, according to Deporter, et al [4] is started from the efforts of Dr. Georgi Lozanov, a Bulgarian educator who experimented with what is called 'suggestology' or 'Sugges-to-pedia'. The main principle is that suggestion can influence the learning results or situations in detail either positively or negatively. In order to give positive suggestions some of the techniques that can be used are comfortably positioning students, setting up background music in the classroom, increasing individual participation, using posters to give a big impression of information prominence, and providing welltrained teachers in the art of teaching [5].

Deporter, et al [4] also claimed that Quantum Learning is tips, guidance, strategies, and the whole learning process that can sharpen understanding and memory, and make learning as a fun and rewarding process. Similarly, in the context, Quantum learning is Foundation, Atmosphere, Design and Environment (abbreviated into FADE model). Its foundation is built on the principles of the 'keys of excellence'. It holds the beliefs that all people can learn, people learn differently, and learning is effective when it is joyful, engaging and challenging. The keys of excellence include integrity, commitment, failure, success, ownership, purposeful speaking, flexibility and balance [6,13]. In summary, Quantum 
Learning emphasizes the arrangement of light, music, and space design, because all these things are considered to affect learners in receiving, absorbing, and processing information. Through the sharpness of students' memory and a fun learning environment, Quantum Learning is the right learning model in increasing students' interest and achievement.

Quantum Learning is based on five main principles. Some of them provide a basis while setting the basic learning system [5].

1) Classroom environment, body language, the planning of the lecture notes and the other all exist in the learning environment. Ideal learning environment includes proper light, carefully selected colors, plants, props and music.

2) Everything is done according to its aim. Because lessons are thought in a careful way as an orchestra.

3) Our brain can be more successful if it is stimulated by the complex stimulants. If new ideas are related to the things that gained without learning, the learning may be more effective.

4) Learning includes risks. But if learning environment is set enjoyably, learning may be easier. If learner follows this step, he considers it safe and may be successful.

5) If something is worth learning it is also worth being celebrated, because, feedback makes positive emotional relations with learning.

The Quantum learning procedures consisting of six stages bound to correlative and mutual complementarity principles. The design called EEL Dr. , C taken from its name from the first letters of the stages and each stage displays part - whole relationship in learning and teaching process. This design consisting of enrolling, experiencing, labeling, demonstrating, reviewing and celebrating phases should cover academic and lifelong learning skills effectively [5 7].

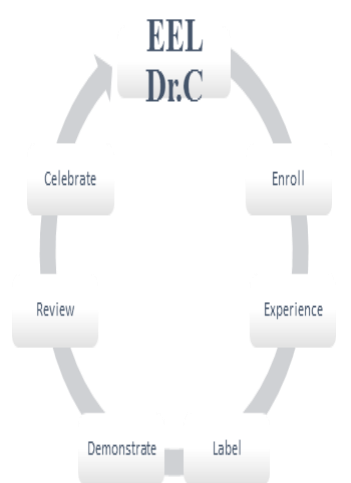

Fig 1:.Quantum Learning Procedures

\subsection{Learning Achievement}

Learning achievement is a sentence consisting of two words namely achievement and learning. Learning and achievement are not dichotomous; they are related. Ambrose and her colleagues [8] defined learning as "a process that leads to change, which occurs as a result of experience and increases the potential for improved performance and future learning." They acknowledged that learning is a 'process, not a product,' and they also suggest that learning involves change, changes in knowledge, beliefs, behaviors, or attitudes.This change unfolds over time; it is not fleeting but rather has a lasting impact on how students think and act. As the result of given experiences, Curzon, et al [9] considered learning as 'apparent modification of a person's behavior through his activities and experiences, so that her or his environment are changed, more or less permanently'. Indeed, changes from the learning experience can be shown in various conditions such as changes in knowledge from not knowing to know, changes in believing things happen for a reason, changes in attitudes or behaviors, and changes in students' learning achievement.

In relation to learning, achievement according to Syah [10] is "a process that allows the appearance of behavioral changes as a result of teaching and learning activities". It can be interpreted that achievement is an important thing that can reflect the various changes in students' learning out comes both the dimensions of creativity, sense and intention. In general, the term achievement refers to the degree or the level success attained in some specific school tasks especially scholastic performance. According to Shazia [11, 12], " learning achievement, in an academic context, is a knowledge attitude or skill developed in the school subject usually designed by test scores or by marks assigned by teacher or by both. Consequently, it could be defined as the self-learning outcome, self-perception or self-evaluation of one's objective success".

\section{Methodology}

This was a quantitative study with quasi-experimental design. Both pre-test and post-test were used as the instruments to collect the data. A total number of 60 students split into experimental and control groups participated in this study. These two groups were given pre-test before the treatment and post-test after the last session of the experiment. These tests were composed 25 questions in the form of Multiple Choice. These test items were firstly validated by using point-biserial correlation $\left(\mathrm{r}_{\mathrm{pbi}}\right)$ formula; due the item scores had a dichotomous variable $(0 / 1)$. In order to interpret the value of $r_{p b i}$, the writer used a " $r$ " critical value table of Pearson Product-moment coefficient, by firstly determining the number of $\mathrm{df}$ calculation $(\mathrm{df}=\mathrm{N}-\mathrm{nr})$. Then, the reliability was determined by correlating the reliability value on "if rxy>rtabel" criteria. The Independent t-test was used to analyze the data.

\section{Findings and Discussions}

Based on the results of the study, the validity of instrument test was conducted on 30 respondents of elementary school students outside the sample research. The instrument types used was the objective test (multiple choice) which amounts to 25 items with 4 options. The material used in this research is about the natural environment, artificial and how to preserve it. The result of validity test showed that there are 15 valid questions and 10 invalid questions (drop). On the contrary, the result of reliability test (with the level of freedom $(\mathrm{dk})=\mathrm{n}-2$ and the significance level of $5 \%$ ) showed that the $r_{\text {tabel }}$ is $(0.361)$; while (r11) is $(0,96)$. It indicated that the research instrument in the study is reliable, where $\mathrm{r} 11$ $(0.96)>r_{\text {tabel }}(0.361)$. Here is the pretest result of the Experimental Class, presented in the frequency distribution table:

Table 1: Frequency Distribution of Experimental Group in Pre-test

\begin{tabular}{|c|c|c|c|c|c|c|}
\hline \multirow[t]{2}{*}{ No } & \multirow[t]{2}{*}{ Class Interval } & \multirow{2}{*}{ Frequency $(f)$} & \multicolumn{2}{|l|}{ Class limit } & \multirow{2}{*}{$\begin{array}{ll}\text { Cumulative } & \text { Fre- } \\
\text { quency }(c f) & \end{array}$} & \multirow{2}{*}{$\begin{array}{l}\text { Relative } \\
\text { Frequency }(r f)\end{array}$} \\
\hline & & & Lower Limit & Upper Limit & & \\
\hline 1 & $4-5$ & 1 & 3.5 & 5.5 & 1 & $3.3 \%$ \\
\hline 2 & $6-7$ & 3 & 5.5 & 7.5 & 4 & $10.0 \%$ \\
\hline 3 & $8-9$ & 10 & 7.5 & 9.5 & 14 & $33.3 \%$ \\
\hline 4 & $10-11$ & 11 & 9.5 & 11.5 & 25 & $36.7 \%$ \\
\hline 5 & $12-13$ & 5 & 11.5 & 13.5 & 30 & $16.7 \%$ \\
\hline 6 & $14-15$ & 0 & 13.5 & 15.5 & 30 & $0.0 \%$ \\
\hline & & 30 & $100 \%$ & & & \\
\hline
\end{tabular}


Table 2: Measures of Central Tendency and Dispersion of Experimental Group in Pre-test

\begin{tabular}{|c|l|c|}
\hline No & \multicolumn{1}{|c|}{ Central Tendency and Dispersion } & Experimental Class \\
\hline 1. & Sample size (n) & 30 \\
\hline 2. & Smallest (min) & 4 \\
\hline 3. & Largest (max) & 13 \\
\hline 4. & Range (R) & 9 \\
\hline 5. & Mean(X) & 9.40 \\
\hline 6. & Median (Me) & 7.68 \\
\hline 7. & Mode(Mo) & 11.83 \\
\hline 8. & Standard Deviation(St-Dev) & 2.09433 \\
\hline
\end{tabular}

Based on statistical calculations, the scores indicated central tendency and dispersion of the pretest value as shown in the table: It can be explained from Table 2 that the pretest results of experimental class, before the quantum learning method was conducted, were in the theoretical range of $0-20$ scores. The achievement of the students were in the range of $4-13$ scores which means the highest scores obtained was 13 and the lowest ones was 4 . The empirical range of 9 , with $n=30$ obtained the mean score of 9.40 , median score of 7.68, the mode of 11.83 and Standard Deviation of 2.09433 .

In taking the posttest data, the writer provided an overview of the students' final ability after obtaining the subject matter. This posttest data was obtained from a written test with the same types of questions number as in pretest. Here is the posttest result of the Control Class, presented in the frequency distribution table:

Table 3: Frequency Distribution of Control Group in Post-test

\begin{tabular}{|c|c|c|c|c|c|c|}
\hline \multirow[t]{2}{*}{ No } & \multirow[t]{2}{*}{ Class Interval } & \multirow[t]{2}{*}{ Frequency $(f)$} & \multicolumn{2}{|c|}{ Class limit } & \multirow{2}{*}{$\begin{array}{c}\text { Cumulative Fre- } \\
\text { quency }(c f)\end{array}$} & \multirow[t]{2}{*}{ Relative Frequency $(r f)$} \\
\hline & & & Lower Limit & Upper Limit & & \\
\hline 1 & $5-6$ & 5 & 4.5 & 6.5 & 9 & $30.3 \%$ \\
\hline 2 & $7-8$ & 12 & 6.5 & 8.5 & 17 & $26.7 \%$ \\
\hline 3 & $9-10$ & 8 & 8.5 & 10.5 & 26 & $30.0 \%$ \\
\hline 4 & $11-12$ & 5 & 10.5 & 12.5 & 27 & $3.3 \%$ \\
\hline 5 & $13-14$ & 0 & 12.5 & 14.5 & 30 & $10.0 \%$ \\
\hline 6 & $15-16$ & 0 & 14.5 & 16.5 & 30 & $0.0 \%$ \\
\hline & & 30 & & & $100 \%$ & \\
\hline
\end{tabular}

Table 4: Measures of Central Tendency and Dispersion of Control Group in Post-test

\begin{tabular}{|c|l|c|}
\hline No & \multicolumn{1}{|c|}{ Central Tendency and Dispersion } & Control Class \\
\hline 1. & Sample size (n) & 30 \\
\hline 2. & Smallest (min) & 5 \\
\hline 3. & Largest (max) & 13 \\
\hline 4. & Range (R) & 8 \\
\hline 5. & Mean (X) & 8.30 \\
\hline 6. & Median (Me) & 8.06 \\
\hline 7. & Mode (Mo) & 8.72 \\
\hline 8. & Standard Deviation (St-Dev) & 2.30666 \\
\hline
\end{tabular}

Table 5: Frequency Distribution of Experimental Group in Post-test

\begin{tabular}{|c|c|c|c|c|c|c|}
\hline \multirow[t]{2}{*}{ No } & \multirow[t]{2}{*}{ Class Interval } & \multirow[t]{2}{*}{ Frequency $(f)$} & \multicolumn{2}{|c|}{ Class limit } & \multirow{2}{*}{$\begin{array}{c}\text { Cumulative Fre- } \\
\text { quency }(c f)\end{array}$} & \multirow{2}{*}{$\begin{array}{l}\text { Relative Fre- } \\
\text { quency }(r f)\end{array}$} \\
\hline & & & Lower Limit & Upper Limit & & \\
\hline 1 & $8-9$ & 5 & 4.5 & 6.5 & 9 & $30.3 \%$ \\
\hline 2 & $10-11$ & 12 & 6.5 & 8.5 & 17 & $26.7 \%$ \\
\hline 3 & $12-13$ & 8 & 8.5 & 10.5 & 26 & $30.0 \%$ \\
\hline 4 & $14-15$ & 5 & 10.5 & 12.5 & 27 & $3.3 \%$ \\
\hline 5 & $16-17$ & 0 & 12.5 & 14.5 & 30 & $10.0 \%$ \\
\hline 6 & $18-19$ & 0 & 14.5 & 16.5 & 30 & $0.0 \%$ \\
\hline & & 30 & & & & \\
\hline
\end{tabular}

Based on statistical calculations above, the scores indicated central tendency and dispersion of the posttest value as shown in the table:

Table 6: Measures of Central Tendency and Dispersion of Experimental Group in Post-test
\begin{tabular}{|c|l|c|}
\hline \multicolumn{1}{|c|}{ Central Tendency and Dispersion } & Experimental group \\
\hline No & \multicolumn{1}{|c|}{30} \\
\hline 1. & Sample size (n) & 8 \\
\hline 2. & Smallest (min) & 15 \\
\hline 3. & Largest (max) & 7 \\
\hline 4. & Range (R) & 11.43 \\
\hline 5. & Mean(X) & 5.1 \\
\hline 6. & Median (Me) & 9.5 \\
\hline 7. & Mode (Mo) & 1.95965 \\
\hline 8. & Standard Deviation (St-Dev) & \\
\hline
\end{tabular}

Based on statistical calculations, the scores indicated central tendency and dispersion of the posttest value as shown in the table:
Table 6 above explained that, the posttest result of experimental class, was taught by quantum learning method, is in the theoretical range $0-20$ scores. Children acquisition $8-15$ scores, means the highest scores obtained by children $=15$ and the lowest values $=8$, then the empirical range $=7$ scores, with $\mathrm{n}=30$ obtained the mean $=11.43$, median $=5.1$, mode $=9.5$, standard deviation $=$ 1.95965.Based on the t-test, it illustrates that the data of posttest values from the experimental class and control class were 5.670 
$\left(\mathrm{t}_{\text {count }}\right)$. The $\mathrm{t}_{\text {table }}$ with the level of freedom $(\mathrm{dk})=58$ and the significance level of $5 \%$ was obtained at 2.02 . This showed that $t_{\text {count }}$ $>t_{\text {table }}$. So it can be concluded that there is a significance difference between the experimental class and control class after the treatment was given or Ho is rejected. Based on the data description, it can be interpreted that there was a significant influence of the use of Quantum Learning Cycles' EEL Dr.C on students' civics education achievement.

\section{Conclusion and Suggestion}

Based on the results of data analysis and hypothesis testing in this study, it can be concluded that Quantum Learning Cycles' EEL Dr.C is effective in maximizing students' civics education achievement, as it was evidenced by the result of t-test calculation obtained $t_{\text {count }}$ at 1.25 and $t_{\text {tabel }}$ of 1.67. Thus $t_{\text {count }}$ is larger than $t_{\text {table }}$ which means the null hypothesis $\left(\mathrm{H}_{0}\right)$ is rejected and the research hypothesis $\left(\mathrm{H}_{1}\right)$ is accepted. Thus, using Quantum Learning Cycles' EEL Dr.C has a positive effect on the achievement of civics education of these primary school students. The results of the analysis showed that the samples were normally distributed and homogeneous.

Based on the research results of this research, it is suggested that teachers should always be innovate to develop his creativity in maximizing their students' knowledge. Besides, the use of effective and appropriate learning model is strongly recommended since the students will grasp the lessons well if they enjoy their learning process. In relation to the use of Quantum Learning $\mathrm{Cy}$ cles' EEL Dr.C, it is expected if further research could do similar research on different subjects towards different level of the students, hence, the effectiveness of this learning model can be measured more.

\section{References}

[1] Suryani N (2013), Improvement of Students' History Learning Competence through Quantum Learning Model at Senior High School in Karanganyar Regency, Solo, Central Java Province, Indonesia. Journal of Education and Practice 4(14), 55-63.

[2] Dadgaran NS \& Khalkhali A (2016), The Effect of Quantum Learning Method on Students Course Learning. Iranian Journal of Medical Education 8(4), 29-36.

[3] Given, Barbara K, DePorter, Bobbi, Conradie \& Dee (2015), Excellence in Teaching and Learning: The Quantum Learning System. Learning Forum Publications.

[4] Deporter B, Hernacki \& Mike (2013), Quantum Learning Membiasakan Belajar Nyamandan Menyenangkan. Terjemahan: Alwiyah Abdurrachman: Cet. I. Bandung, Indonesia: Penerbit Kaifa Nizan Media Utama.

[5] DePorter B, Reardon M \& Nourie SS (1999), Quantum TeachingTeaching Orchestrating Student Success. A Viacom Company.

[6] Reid G (2005), Learning Styles and Inclusion. London, UK: Sage Publications Ltd.

[7] Uhrmacher P, Bruce, Bradley M, Conrad, Christy M \& Moroye (2013), Finding the Balance Between Process and Product Through Perceptual Lesson Planning. Journal ofTeachers College Record 115, $27 \quad 070303, \quad$ July 2013 http://www.crispateaching.org/uploads/1/3/6/4/13645071/finding_t he_balance_between_process_and_product_through_perceptual_les son_planning.pdf.

[8] Ambrose, Susan A. et al (2010), How Learning Works: 7 ResearchBased Principles for Smart Teaching. San Francisco, CA: Jossey Bass.

[9] Curzon LB, Tummons \& Jonathan (2013), Teaching in Further Education: An Outline of Principles and Practice. New York, USA: Bloomsbury.

[10] Syah \& Muhibbin (2006), Pendidikan SuatuPendekatanBaru: Cet. 15. Bandung, Indonesia: PT. Remaja Rosdakarya.

[11] Shazia \& Siraj (2014), Self-Concept, Learning Styles, Study Habits and Academic Achievement of Adolescents in Kashmir: A Study on Psychological Variables and Academic Achievement of Adolescents in Kashmir. Anchor Academic Publishing.
[12] Alshemmeri, F., Putih, A., Siraj, S., Khan, A., Abdallah, N. (2011) Art Ability and Academic Achievement in the Kingdom of Saudi Arabia: Role of Age and Sex. New Educational Review, 26 (4), 238-247

[13] Khan, A., Shin, L.P., Hishan, S.S., Mustaffa, M.S., Madihie, A., \& Sabil, S. (2018). Effect of personality traits and learning styles towards students' academic achievement in Johor Bahru. International Journal of Engineering \& Technology, 7 (2.10), 4-9. 